\title{
DNA Methylation and Ciliopathies: a way to be explored
}

\author{
M Alvarez-Satta ${ }^{1,2^{*}}$, L De Chiara ${ }^{1,2}$, S Castro-Sánchez ${ }^{1,2}$, D Valverde ${ }^{1,2}$ \\ From Cilia 2014 - Second International Conference \\ Paris, France. 18-21 November 2014
}

\section{Objective}

Since the molecular basis underlying ciliopathies such as Bardet-Biedl (BBS) or Alström (ALMS) syndromes is not fully understood, we hypothesised that changes in pattern of DNA methylation, due to its role in embryogenesis and differentiation, could be a mechanism that explains the pathogenesis of these diseases.

\section{Methods}

CpG islands search was performed by Methyl Primer Express software 11.0 (Applied Biosystems) in the promoter region of $A L M S 1, B B S 1, B B S 2, B B S 6, B B S 7$, $B B S 9, B B S 10$ and $B B S 12$ genes. In order to quantify the degree of methylation, we carried out MS-qPCR using SYBR $^{\circledR}$ Select Master Mix (Applied Biosystems). Blood lymphocyte DNA samples from seven patients with ALMS were selected.

\section{Results}

Regarding to bioinformatic analysis, all genes harboured at least one CpG island. Some of them included one or more sequences compatible with $x$-box motifs, which can be recognized by transcription factors of RFX family that are known to be involved in the regulation of ciliary genes transcription.

We selected a CpG island in the ALMS1 gene containing 67 cytosine residues potentially methylated for performing MS-qPCR. A mean efficiency ranging from 90 to $96 \%$ was reached for each amplicon in which the $\mathrm{CpG}$ island was divided. Unfortunately, no methylation was detected in the enrolled patients.

'Department of Biochemistry, Genetics and Immunology, University of Vigo, Vigo, Spain

Full list of author information is available at the end of the article

\section{Conclusion}

Although the results of this preliminary study were negative, limitations due to sample size, sample type and experimental approach have to be taken into account. However, we consider it worth exploring this mechanism in BBS and ALMS using different techniques such as methylation arrays, which could provide more accurate data.

\section{Authors' details}

'Department of Biochemistry, Genetics and Immunology, University of Vigo, Vigo, Spain. ${ }^{2}$ Instituto de Investigación Biomédica Ourense-Pontevedra-Vigo $(|B|)$, Vigo, Spain.

Published: 13 July 2015

doi:10.1186/2046-2530-4-S1-P10

Cite this article as: Alvarez-Satta et al:: DNA Methylation and Ciliopathies: a way to be explored. Cilia 2015 4(Suppl 1):P10.

Submit your next manuscript to BioMed Central and take full advantage of:

- Convenient online submission

- Thorough peer review

- No space constraints or color figure charges

- Immediate publication on acceptance

- Inclusion in PubMed, CAS, Scopus and Google Scholar

- Research which is freely available for redistribution

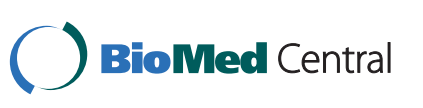

(c) 2015 Alvarez-Satta et al. This is an Open Access article distributed under the terms of the Creative Commons Attribution License (http://creativecommons.org/licenses/by/4.0), which permits unrestricted use, distribution, and reproduction in any medium, provided the original work is properly cited. The Creative Commons Public Domain Dedication waiver (http://creativecommons.org/ publicdomain/zero/1.0/) applies to the data made available in this article, unless otherwise stated. 